\title{
IMMEDIATE AND LATE EFFECT OF SUTURES IN EXTRASYNOVIAL TENDONS: BIOMECHANICAL STUDY IN RATS
}

Trajano Sardenberg ${ }^{1}$, Sérgio Swain Muller ${ }^{1}$, Luciana Zauhy Garms ${ }^{2}$, Francini Belluci Miduati ${ }^{2}$

\section{ABSTRACT}

Objective: The aim of this study was to evaluate the effects on the mechanical properties of rats' calcaneus tendons, of repair arrangements using suture material in the absence of any healing process. Method: Twelve male Wistar rats were used. They were subjected to placement of a modified Kessler suture stitch in the calcaneus tendon. The sacrifices were performed immediately after and six weeks after the operation. The mechanical properties studied were maximum load, tension in the maximum load and module of elasticity. The contralateral tendon was used as a control. Results: The statistical analysis showed that for the times studied, the values for mechanical properties did not present any significant differences. In relation to the control, i.e. the contralateral tendon without a suture, the results demonstrated that, six weeks after the operation, the values for the modulus of elasticity were lower, whereas there were no significant variations in maximum load or tension at maximum load. Conclusion: Placement of suture material on an extrasynovial tendon without lesions decreased the modulus of elasticity, but it did not interfere with the maximum load or tension at maximum load, six weeks after the operation.

Keywords - Suture; Tensile Strength; Calcaneus Tendon; Rats; Biomechanics

\section{INTRODUCTION}

Surgical treatment for tendon injuries can be done using several repair techniques, but they always involve placement of suture material. The arrangement of the suture needs to maintain the apposition of the tendon stumps, preferably under conditions of movement.

During the healing process, the suture thread should cause minimal tissue reaction and should have sufficient resistance to traction forces. Therefore, the arrangement and the suture material influence the healing process ${ }^{(1-3)}$. McDowell et $\mathrm{al}^{(4)}$ demonstrated that placing a suture thread in an uninjured tendon promoted a tissue reaction at the tendon/thread interface that interfered with the mechanical, histological and biochemical properties of intrasynovial tendons. Wong et $\mathrm{al}^{(5)}$ demonstrated the existence of areas of acellularity in both vascularized and avascular tendons, after placement of knotted sutures in tendons in rabbits and rats. Although extrasynovial tendons present differences in the nutrition and healing processes in relation to intrasynovial tendons, it may be supposed that interference in mechanical properties also occurs in these tendons, caused by the presence of suture threads in repair arrangements, even in the absence of a healing process.

By making a suture arrangement in a complete tendon, i.e. without injury, the effects of the arrangement and suture material on the tendon can be evaluated in isolation, without the healing process.

The aim of the present investigation was thus to assess the possible effect of the repair arrangement with suture material, on the mechanical properties of the calcaneal tendon of rats, in the absence of a healing process.

1. PhD. Professor in the Botucatu Medical School, UNESP, São Paulo, Brazil.

2. Physician and former resident in Orthopedics and Traumatology, Botucatu Medical School, UNESP, São Paulo, Brazil.

Work performed in the Department of Surgery and Orthopedics, Botucatu Medical School, UNESP, São Paulo, Brazil.

Correspondence: Departamento de Cirurgia e Ortopedia da Faculdade de Medicina de Botucatu - UNESP - Distrito de Rubião Junior, s/n - 18603-970 - Botucatu, SP.

Email: tsarden@uol.com.br

Work received for publication: July 2, 2010; accepted for publication: November 3, 2010 


\section{METHODS}

The study received prior approval from the institution's Animal Ethics Committee.

Twelve male rats of Wistar lineage were used. They were 60 days of age, with a mean weight of $242 \mathrm{~g}$, and were clinically healthy.

These animals were subjected to a surgical procedure as follows. General anesthesia was effected using sodium pentobarbital $(30 \mathrm{mg} / \mathrm{kg})$, administered intraperitoneally. Then, a posterior access was made in the left hind leg, the calcaneal tendon was isolated and a modified Kessler suture stitch was inserted using 6-0 nylon thread. The skin was sutured using 5-0 Monocryl and an occlusive dressing was applied (Figures 1 and 2). No type of immobilization was used.

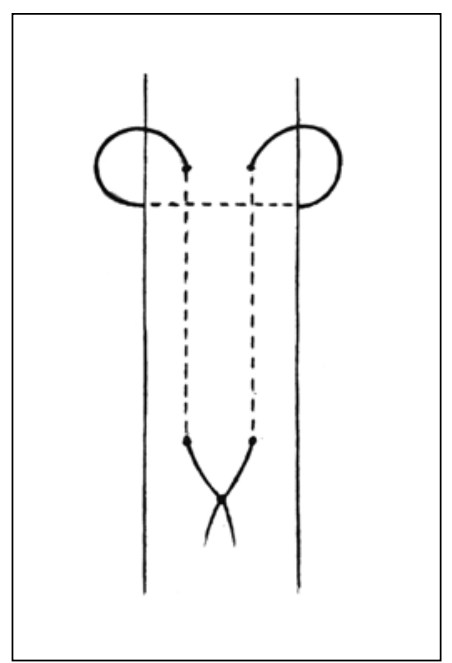

Figure 1 - Schematic drawing of the suture stitch made in the calcaneal tendon of the rat.

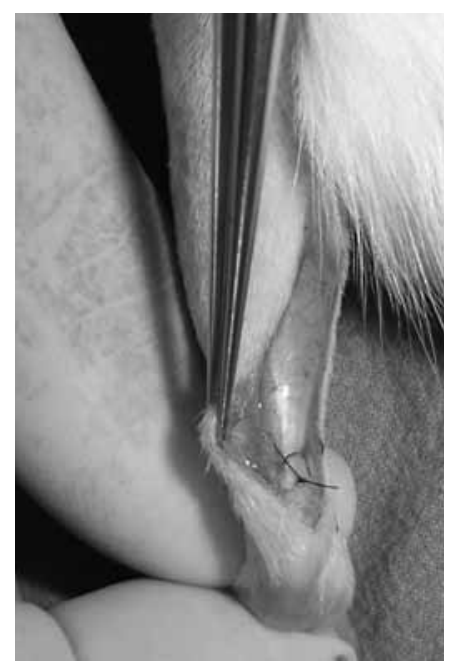

Figure 2 - Appearance of the hind leg of the rat, showing the calcaneal tendon with the suture stitch.
The rats were subsequently killed for the biomechanical evaluation: six animals selected during the immediate postoperative period and the remaining six animals, six weeks after the operation.

The tendons were dissected, removed (Figure 3) and fixed axially in clamps that were specially developed for this study. The distance between the clamps was $6 \mathrm{~mm}$ (Figure 4).

The mechanical tests were performed on a universal mechanical testing machine, with a velocity of 30 $\mathrm{mm} / \mathrm{min}$. The mechanical properties studied were: maximum load $(\mathrm{N})$, tension at maximum load $(\mathrm{MPa})$ and modulus of elasticity (MPa).

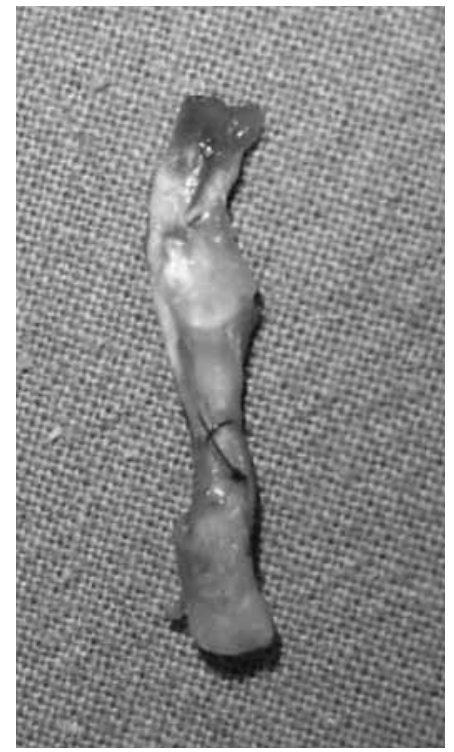

Figure 3 - Isolation of the calcaneal tendon of the rat with the suture stitch before the biomechanical test.

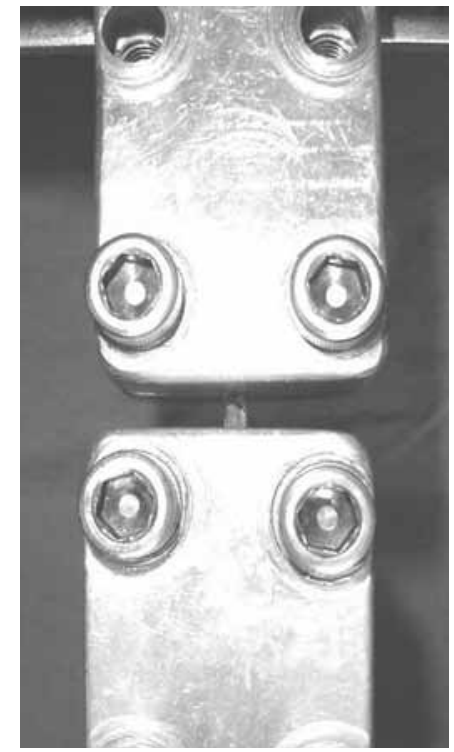

Figure 4 - Test body (tendon) mounted on the mechanical testing machine.
After the traction test, the computer that was coupled to the testing machine furnished a load-deformation diagram.

The contralateral tendon was used as a control.

The results were subjected to statistical evaluation using the technique of analysis of variance for the model of repeated measurements for independent samples ${ }^{(6)}$.

\section{RESULTS}

Tables 1, 2 and 3 present the means and standard deviations of the mechanical properties studied, on the operated side and the contralateral side (control) at the times assessed (immediately and six weeks after the operation), and the statistical analysis.

Figures 5, 6 and 7 illustrate the results obtained for each mechanical property.

Table 1 - Means and standard deviations of the maximum load (N) according to the time of sacrifice and group.

\begin{tabular}{c|c|c|c}
\hline \multirow{2}{*}{ Time of sacrifice } & \multicolumn{2}{|c|}{ Group } & \multirow{2}{*}{$\begin{array}{c}\text { Result from } \\
\text { group test }\end{array}$} \\
\cline { 2 - 3 } & Control (C) & Suture (S) & \\
\hline Immediate (I) & $64 \pm 15.9$ & $60 \pm 16.5$ & $p>0.05(\mathrm{C}=\mathrm{S})$ \\
$\begin{array}{c}\text { Six weeks after } \\
\text { operation (A) }\end{array}$ & $72 \pm 8.6$ & $77 \pm 16.3$ & $\mathrm{p}>0.05(\mathrm{C}=\mathrm{S})$ \\
\hline $\begin{array}{c}\text { Result from } \\
\text { time test }\end{array}$ & $\begin{array}{c}\mathrm{p}>0.05 \\
(\mathrm{I}=\mathrm{A})\end{array}$ & $\begin{array}{c}\mathrm{p}>0.05 \\
(\mathrm{I}=\mathrm{A})\end{array}$ & \\
\hline
\end{tabular}


Table 2 - Means and standard deviation of the tension at maximum load (MPa) according to the time of sacrifice and group.

\begin{tabular}{c|c|c|c}
\hline \multirow{2}{*}{ Time of sacrifice } & \multicolumn{2}{|c|}{ Group } & \multirow{2}{*}{$\begin{array}{c}\text { Result from } \\
\text { group test }\end{array}$} \\
\cline { 2 - 3 } & Control (C) & Suture (S) & \\
\hline $\begin{array}{c}\text { Immediate (I) } \\
\text { Six weeks after } \\
\text { operation (A) }\end{array}$ & $21 \pm 11.1$ & $24 \pm 6.9$ & $\mathrm{p}>0.05(\mathrm{C}=\mathrm{S})$ \\
\hline $\begin{array}{c}\text { Result from time } \\
\text { test }\end{array}$ & $\begin{array}{c}\mathrm{p}>0.05 \\
(\mathrm{I}=\mathrm{A})\end{array}$ & $\begin{array}{c}\mathrm{p}>0.05 \\
(\mathrm{I}=\mathrm{A})\end{array}$ & \\
\hline
\end{tabular}

Table 3 - Means and standard deviations of the modulus of elasticity (MPa) according to the time of sacrifice and group.

\begin{tabular}{c|c|c|c}
\hline \multirow{2}{*}{ Time of sacrifice } & \multicolumn{2}{|c|}{ Group } & \multirow{2}{*}{$\begin{array}{c}\text { Result from } \\
\text { group test }\end{array}$} \\
\cline { 2 - 3 } & Control (C) & Suture (S) & \\
\hline Immediate (I) & $37 \pm 8.6$ & $46 \pm 6.7$ & $\mathrm{p}>0.05(\mathrm{C}=\mathrm{S})$ \\
$\begin{array}{c}\text { Six weeks after } \\
\text { operation (A) }\end{array}$ & $63 \pm 14.0$ & $48 \pm 5.8$ & $\mathrm{p}<0.05(\mathrm{C}>\mathrm{S})$ \\
\hline $\begin{array}{c}\text { Result from time } \\
\text { test }\end{array}$ & $\begin{array}{c}\mathrm{p}<0.01 \\
(\mathrm{I}<\mathrm{A})\end{array}$ & $\begin{array}{c}\mathrm{p}>0.05 \\
(\mathrm{I}=\mathrm{A})\end{array}$ & \\
\hline
\end{tabular}

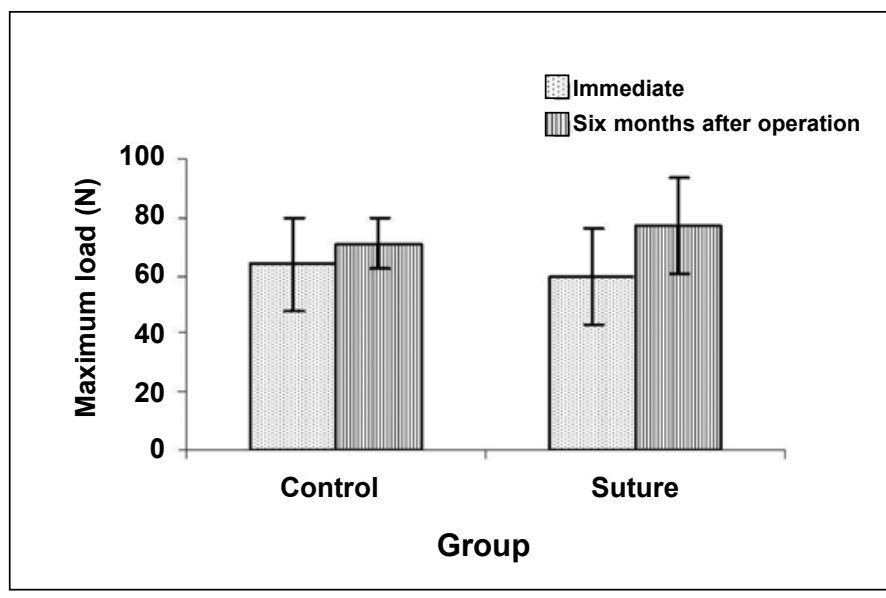

Figure 5 - Means and standard deviations of the maximum load (N) according to time of sacrifice and group.



Figure 6 - Means and standard deviations of the tension at maximum load (MPa) according to time of sacrifice and group.

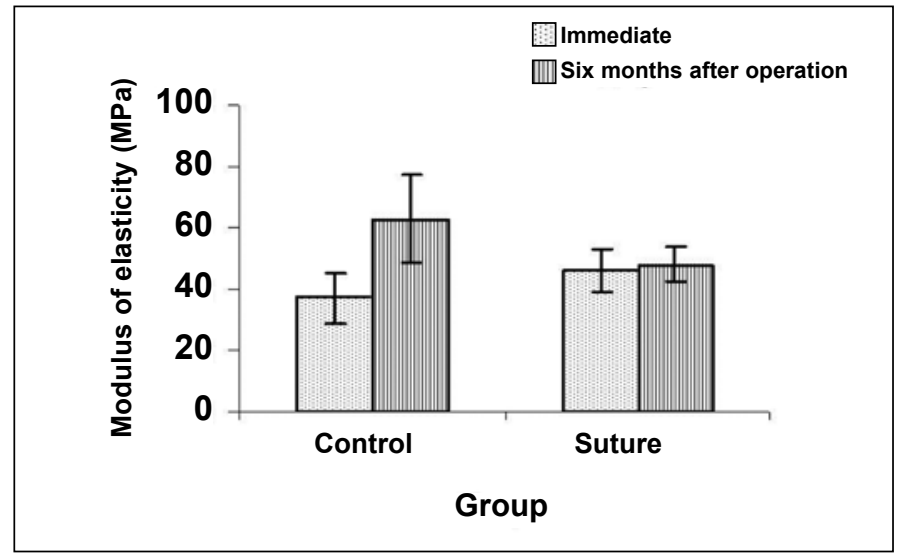

Figure 7 - Means and standard deviations of the modulus of elasticity (MPa) according to time of sacrifice and group.

The statistical analysis indicated that, in relation to the times studied (immediately and six weeks after the operation), the values for the mechanical properties did not present significant differences. In relation to the control, i.e. the contralateral tendon without a suture, the statistical evaluation demonstrated that, six weeks after the operation, the values for the modulus of elasticity were lower, while maximum load and tension at maximum load did not show any significant variance.

\section{DISCUSSION}

The present investigation was limited to a mechanical evaluation on the effect of placing a suture stitch in an uninjured tendon, during the immediate postoperative period and six weeks after the operation.

The results obtained indicated that the mechanical behavior of the operated tendons remained stable, i.e. the values observed immediately after the operation were similar to those found six weeks after the operation. In a similar study on flexor tendons in hens, McDowell et al ${ }^{(4)}$ observed that the mechanical properties decreased over the first postoperative weeks, with subsequent recovery to values close to the initial values after 28 days. It is possible that a similar phenomenon could have occurred in the present investigation, but with a more accentuated recovery after six weeks. However, this is just a supposition, given that no mechanical tests were carried out at other times, i.e. between the immediate postoperative period and six weeks after the operation. In the literature relating to tendon healing, there are reports of studies on 
mechanical behavior in which a slight fall was presented up to 20 days after the operation, with slow and progressive recovery thereafter, becoming more accentuated six weeks after the operation. On the other hand, there are studies in which stabilization or a slight increase is seen right from the start of the repair, followed by a more accentuated increase six weeks after the operation. Despite significant methodological differences and differences in the subjects between these studies, which creates difficulty and limitations regarding comparisons between the results, there are indications that after a six-week period, greater recovery of mechanical properties occurs, compared with the immediate postoperative period ${ }^{(7-13)}$.

The analysis on the values of the mechanical properties of the tendons that were operated, in comparison with the contralateral controls, indicated the degree of recovery of mechanical behavior. In the present investigation, the values observed in the immediate postoperative period and six weeks after the operation were similar to those of the controls, and this suggests that placing a suture stitch on uninjured tendons did not significantly interfere with the mechanical properties of the calcaneal tendons of rats. The only discordance from this pattern occurred with regard to the modulus of elasticity, for which the values of the operated tendon were lower than those of the controls, among the animals kept until reaching six weeks after the operation. It is possible that the biological reaction of the tendon to the presence of the suture thread may have interfered with the parallelism of the collagen distribution in the tendon and may have caused a decline in the values of this mechanical property, given that nonparallel morphological tissue arrangements are associated with greater deformation required for rupture and consequently, a lower modulus of elasticity ${ }^{(14,15)}$.

\section{CONCLUSION}

Under the conditions of this investigation in rats, placement of suture material in an uninjured extrasynovial tendon caused a decrease in the modulus of elasticity, but it did not interfere with the maximum load and the tension at the maximum load, six weeks after the operation.

\section{REFERENCES}

1. Sobania LC, Santos OS. Lesões dos tendões flexores. In: Pardini A, Freitas A Traumatismos de mão. Rio de Janeiro: Medsi; 2003. p.17-350.

2. Beredjklian PK. Biologic aspects of flexor tendons laceration and repair. J Bone Joint Surg Am. 2003;85(3):539-50.

3. Muller SS, Sardenberg T, Danieli MV, Pizol F, Padovani CR. Avaliação biomecânica de sutura tendinosa com três tipos de fios cirúrgicos - estudo experimental em cães. Rev Bras Ortop. 2003;38(3):117-26.

4. McDowell C, Marqueen TJ, Yager D, Owen JR, Wayne JS. Characterization of the tensile properties and histologic/biochemical changes in normal chicken tendon at the site of suture insertion. J Hand Surg Am. 2002;27(4): 605-14.

5. Wong JKF, Cerovac S, Ferguson MW, Macgrouther DA. The cellular effect of a single interrupted suture on tendon. J Hand Surg Br. 2006;31(4):358-67.

6. Johnson RA, Winchern DW. Applied multivariate statistical analysis. 4th ed. New Jersey: Prentice-Hall;1998. p. 642.

7. Gelberman RH, Woo SLY, Lothringer K, Akeson WH, Amiel D. Effects of early intermittent passive immobilization on healing canine flexor tendons. J Hand Surg Am. 1982;7(2):170-5.

8. Defino HL, Barbieri CH, Gonsalves RP, Paulin JB. Estudo experimental comparativo das técnicas de Kessler e Tsuge para sutura tendinosa. Rev Bras Ortop. 1985;20(5):211-8.

9. Hitchcock TF, Light TR, Bunch WH, Knight GW, Sartori MJ, Patwardhan AG et

Rev Bras Ortop. 2011;46(3):305-08 al. The effect of immediate constrained digital motion on the strength of flexor tendon repair in chickens. J Hand Surg Am. 1987;12(4):590-5.

10. O'Broin ES, Earley MJ, Smyth H, Hooper ACB. Absorbables sutures in tendon repair. A comparison of PDS with Prolene in rabbit tendon repair. J Hand Surg Br. 1995;20(4):505-8.

11. Mass DP, Tuel RJ, Labarbera M, Greenwald DP. Effects of constant mechanical tension on the healing rabbit flexor tendons. Clin Orthop Relat Res. 1993;(296):301-6.

12. Winters SC, Gelberman RH, Woo SLY, Chan SS, Grewal R, Seiler JG. The effects of multiple-strand suture methods on the strength and excursion of repaired intrasynovial flexor tendons: a biomechanical study in dogs. J Hand Surg Am. 1998;23(1):97-104.

13. Boyer MI, Gelberman RH, Burns ME, Dinopoulos H, Hoferm R, Silva MJ. Intrasynovial flexor tendon repair: an experimental study comparing low and high levels of in vivo force during rehabilitation in canines. J Bone Joint Surg Am. 2001;83(6):891-9.

14. Müller SS. Análise comparativa das propriedades mecânicas do ligamento da patela e do tendão calcâneo: estudo experimental em cadáveres humanos [tese] Botucatu: Faculdade de Medicina Universidade Estadual Paulista; 1998.

15. Viidik A. Biomechanical behavior of soft connective tissues. In: Akkas N. Progess in biomechanics. Apen aan den Rijn: Sijthoff and Nordhoff; 1979. p.75-113. 